\title{
Sugarcane mosaic virus infects Stenotaphrum secundatum in Australia
}

\author{
Nga T. $\operatorname{Tran}^{1}{ }^{1}$ - Ai Chin Teo ${ }^{1} \cdot$ John E. Thomas ${ }^{1} \cdot$ Kathleen S. Crew $^{1,2} \cdot$ Andrew D. W. Geering $^{1}$
}

Received: 28 September 2020 / Accepted: 2 November 2020 / Published online: 16 November 2020

(C) Australasian Plant Pathology Society Inc. 2020

\begin{abstract}
This study presents the first report of sugarcane mosaic virus (SCMV) infecting Stenotaphrum secundatum (buffalo grass) in Australia, from a turf farm in the Hunter Valley, New South Wales. The plant displayed mosaic symptoms and contained flexuous, filamentous virions of 700-750 $\times 10-11 \mathrm{~nm}$ typical of members of the genus Potyvirus. Infection of the sample by SCMV was confirmed by double antibody sandwich ELISA and RT-PCR amplification of the coat protein coding region of the viral genome. In a phylogenetic analysis, the buffalo grass isolate was sister to a clade of maize-infecting isolates of SCMV from eastern Africa and was $75.8 \%$ and $79.4 \%$ identical to the exemplar isolate of SCMV at nucleotide and amino acid levels, respectively.
\end{abstract}

Keywords Potyvirus $\cdot$ Buffalo grass $\cdot$ St. Augustinegrass $\cdot$ Nucleotide sequence

Stenotaphrum secundatum (buffalo grass in Australia or St. Augustinegrass in the USA) is a hardwearing and vigorous warm season turfgrass species, thought to be endemic to the Atlantic coasts of the Americas and Africa (Sauer 1972; Busey 2003). It is the most important turf species in Australia based on the value of its production (Hort Innovation 2019). Sugarcane mosaic virus (SCMV), an aphid-transmitted virus in the genus Potyvirus, was first identified as a pathogen of $S$. secundatum in the Canal PointPahokee-Belle Glade sugarcane growing region of Florida in 1963 (Todd et al. 1964). SCMV was not considered a serious problem to the turf industry in Florida until an outbreak of a lethal necrosis disease occurred in 2013 on 50 residential lawns within a $10 \mathrm{~km}$ radius of the Bayway Isles community in south St. Petersburg (Harmon 2014; Harmon et al. 2015). Aside from the severity of the symptoms, this disease outbreak was notable as it represented the first record of SCMV on $S$. secundatum outside of the sugarcane growing region of southern Florida, and also occurred on cv. 'Floratam', the most popular cultivar in the State.

Nga T. Tran

n.tran3@uq.edu.au

1 Centre for Horticultural Science, Queensland Alliance for Agriculture and Food Innovation, The University of Queensland, Ecosciences Precinct, Dutton Park, Queensland 4102, Australia

2 Department of Agriculture and Fisheries, Ecosciences Precinct, Dutton Park, Queensland 4102, Australia
SCMV has a worldwide distribution and infects several economically important monocotyledonous crops including maize (Zea mays), sorghum (Sorghum bicolor) and sugarcane (Saccharum officinarum) (Yang and Mirkov 1997; Wu et al. 2012). In Australia, there are three described strains of SCMV that are named after their primary natural hosts, namely sugarcane (S. officianarum), Sabi grass (Urochloa mosambicensis) and Queensland blue couch grass (Digitaria didactyla) (Teakle and Grylls 1973; Gough and Shukla 1981). The known natural host ranges of these SCMV strains in Australia are limited to single plant species, except for the Queensland blue couch strain, which has also been found in Axonopus compressus, Digitaria adscendens, Paspalum dilatatum and Z. mays (Teakle and Grylls 1973). All validated Australian records of SCMV are from Queensland (Teakle and Grylls 1973; Handley et al. 1996, 1998), although this most likely reflects limited surveillance and diagnostic efforts rather than true geographic range.

In June 2019, a sample of $S$. secundatum cv. 'Sir Walter' from a turf farm in the Hunter Valley, New South Wales, Australia was submitted for disease diagnosis (Queensland Department of Agriculture and Fisheries Plant Virus Collection isolate 5599). A mosaic pattern was present on the leaves, suggestive of a viral infection (Fig. 1a). Flexuous, filamentous virions of $700-750 \times 10-11 \mathrm{~nm}$ were observed in negatively contrasted sap extracts of symptomatic leaf tissue using a JEOL JEM-1400 transmission electron microscope, consistent with the plant being infected with a potyvirus. Supporting this hypothesis, a positive reverse 


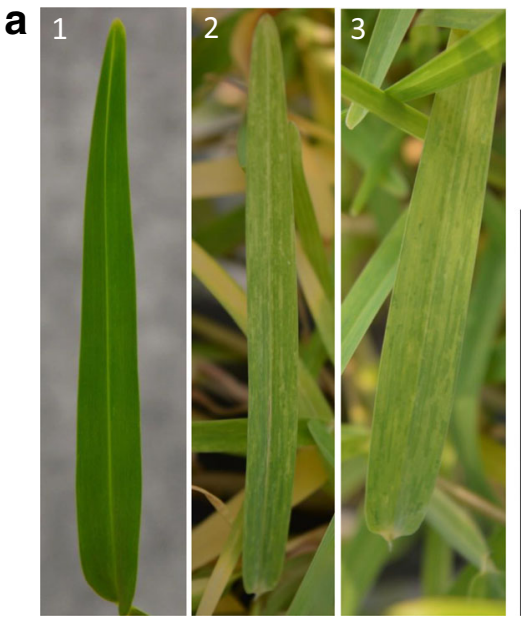

Fig. 1 (a) Stenotaphrum secundatum cv. 'Sir Walter': (1) healthy and (2, 3) infected by virus isolate 5599; (b) Reverse transcription-PCR detection of sugarcane mosaic virus (SCMV) using primers to amplify the entire coat protein coding region of the viral genome: lanes 1 and 6 ,

transcription (RT)-PCR result was obtained when a total nucleic acid extract from symptomatic tissue, prepared using a Biosprint 15 DNA Plant Kit (QIAGEN, Hamburg, Germany) as per the manufacturer's instructions but without the RNase A digestion step, was tested with the universal potyvirus primer set U341/D341 (Langeveld et al. 1991) using a MyTaq One-Step RT-PCR Kit (Bioline Meridian Bioscience, Memphis, USA). The RT-PCR thermocycling conditions were: one cycle each at $45{ }^{\circ} \mathrm{C}$ for $20 \mathrm{~min}$ and $95^{\circ} \mathrm{C}$ for $1 \mathrm{~min} ; 40$ cycles of $95^{\circ} \mathrm{C}$ for $10 \mathrm{~s}, 50{ }^{\circ} \mathrm{C}$ for $10 \mathrm{~s}$ and $72{ }^{\circ} \mathrm{C}$ for $30 \mathrm{~s}$ each; followed by a final extension at $72^{\circ} \mathrm{C}$ for $2 \mathrm{~min}$. The amplicon was then electrophoresed on a $1.5 \%$ agarose gel and stained with ethidium bromide. Sequencing of the amplicon at Macrogen Incorporated (South Korea) using an AB 3730xl DNA Analyzer (Applied Biosystems, Foster City CA, USA) narrowed the diagnosis to SCMV. The sample was then tested using a SCMV double-antibody sandwich ELISA kit (Creative Diagnostics, Shirley, NY 11967, USA) following the manufacturer's instructions but with half volumes and $\mathrm{A}_{405 \mathrm{~nm}}$ values that were 67 times greater than the mean of two healthy 'Sir Walter' replicates were obtained.

To sequence the coat protein $(\mathrm{CP})$ coding region of the viral genome, primers SCMV-NIb-F1 (5' ATWGCMGARACAGC ACTCCG 3') and SCMV-UTR-R1 (5' CCTGTRTCCTGCAG ACTGG $3^{\prime}$ ) were designed by aligning sequences of the nuclear inclusion protein $(\mathrm{NIb})$ and $3^{\prime}$ untranslated regions of the genomes of SCMV isolates that had the highest scoring matches from a BLASTN search of the NCBI Nucleotide Database using the previously derived cDNA sequence as the query. RT-PCR and sequencing was done as described previously except that a primer annealing temperature of $65^{\circ} \mathrm{C}$ was used. The amplicon (Fig. 1b), excluding the primers, was 1165 nucleotides long and its sequence has been deposited in b

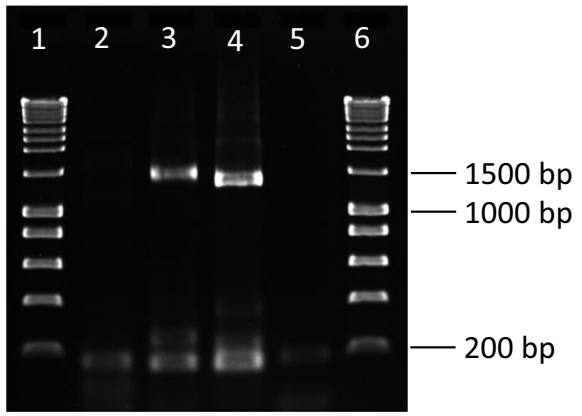

HyperLadder $1 \mathrm{~kb}$ (Bioline); lane 2, healthy cv. 'Sir Walter'; lane 3, virus isolate 5599 from cv. 'Sir Walter'; lane 4, SCMV positive control, virus isolate 5610 from Urochloa mosambicensis; lane 5, no template control

GenBank under accession MW026606. The CP of the virus was identifiable after conceptual translation of the cDNA sequence, and its N-terminus was defined by a conserved serine protease cleavage site (EEVTHQ/SGT) (Adams et al. 2005). Interestingly, the CP contained two copies of the DAG motif associated with aphid transmission, one at amino acid position 5 (proximal) and one at position 112 (distal) from the N-terminus of the CP. Nigam et al. (2019) reported this feature in 77 out of 91 SCMV isolates examined.

Phylogenetic analysis of the $\mathrm{CP}$ nucleotide sequence placed virus isolate 5599 as sister to a clade of maize-infecting isolates of SCMV from eastern Africa, and in a different clade to a sugarcane isolate from Australia and a S. secundatum cv. 'Floratam' isolate from Florida (Fig. 2). Neither the Queensland blue couch nor the Sabi grass strains of SCMV from Australia have been sequenced, so comparisons were not possible. Pairwise sequence comparisons using Geneious Prime (version 2020.0.5, Biomatters, Auckland, New Zealand) showed that the CP of virus isolate 5599 was $75.8 \%$ and $79.4 \%$ identical to the exemplar isolate of SCMV (GenBank accession AJ297628) at nucleotide and amino acid levels, respectively.

To our knowledge, this is the first host record for SCMV in S. secundatum in Australia, and the first location record for this virus in New South Wales. Previously, Pares and Gillings (1990) reported a Johnsongrass strain of SCMV infecting a S. secundatum plant collected from the Hawkesbury Valley, west of Sydney. However, following taxonomic revisions, this record would now be considered that of Johnsongrass mosaic virus (JGMV), a close relative of SCMV (Shukla et al. 1989). Although the identification was only based on differential trapping of virions by immunosorbent electron microscopy using antibodies against SCMV and JGMV, the record can 


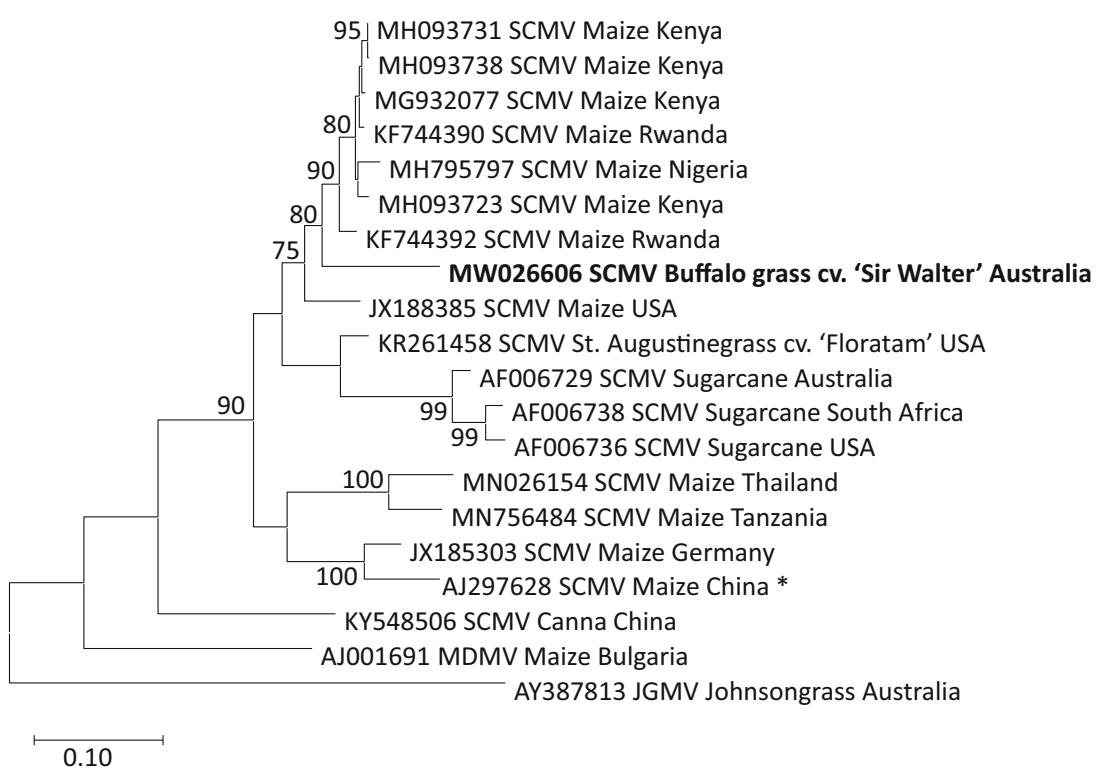

Fig. 2 Phylogram showing inferred evolutionary relationships of virus isolate 5599 from cv. 'Sir Walter' (GenBank accession MW026606, bold font) with other sugarcane mosaic virus (SCMV) isolates from around the world, based on coat protein nucleotide sequences. The tree was constructed using the Maximum Likelihood method implemented in MEGA X. Bootstrap values calculated from 1000 replicates are shown

be considered reliable as the two virus species are serologically distantly related (Shukla et al. 1989).

Recent experience from Florida suggests that SCMV has the potential to be an economically important pathogen for the Australian turf industry. SCMV is non-persistently transmitted by aphids and the use of insecticides is not recommended for control as the aphids can acquire and transmit the virus in a matter of seconds, before the insecticide kills the aphid, and transmissions are mostly by migratory, winged forms of the aphid, not those colonizing the plant (Harmon 2014). Disease control methods recommended in Florida include sanitation of equipment when mowing multiple lawns and the use of tolerant cultivars such as 'Palmetto' and 'Bitterblue' (Harmon 2014). SCMV has a wide range of wild and cultivated hosts in the Poaceae but the host range varies according to the particular strain of the virus (Xiao et al. 1993; Yang and Mirkov 1997) and this aspect of the epidemiology of SCMV on S. secundatum in Australia needs to be investigated. Virus-like symptoms have been observed on a range of cultivars of $S$. secundatum in other turf farms nearer to Sydney by the authors and expanded surveys for SCMV as well as Panicum mosaic virus (Thomas and Steele 2011) are therefore warranted.

Acknowledgements This study was supported by Hort Innovation (Grant TU19000), using the turf industry research and development levy and contributions from the Australian Government. Hort Innovation is the grower-owned, not-for-profit research and development corporation for Australian horticulture. We thank Sari Nurulita for technical support. in branch nodes, and only values greater than $70 \%$ are included. Virus isolates are listed by GenBank accession followed by virus acronym, host plant and country of origin. The exemplar isolate of SCMV is indicated by an asterisk (*). Outgroups are maize dwarf virus (MDMV) and Johnsongrass mosaic virus (JGMV). The scale bar represents numbers of substitutions per site

\section{References}

Adams MJ, Antoniw JF, Beaudoin F (2005) Overview and analysis of the polyprotein cleavage sites in the family Potyviridae. Mol Plant Pathol 6:471-487

Busey P (2003) St. Augustinegrass, Stenotaphrum secundatum (Walt.) Kuntze. In: Casler M, Uncan R (eds) Turfgrass biology, genetics and breeding, genetics. John Wiley \& Sons, Hoboken, pp 309-330

Gough KH, Shukla DD (1981) Coat protein of potyviruses. I Comparison of the four Australian strains of sugarcane mosaic virus. Virology 111:455-462

Handley J, Smith G, Dale J, Harding R (1996) Sequence diversity in the $\mathrm{NIb}$ coding region of eight sugarcane mosaic potyvirus isolates infecting sugarcane in Australia. Arch Virol 141:2289-2300

Handley J, Smith G, Dale J, Harding R (1998) Sequence diversity in the coat protein coding region of twelve sugarcane mosaic potyvirus isolates from Australia, USA and South Africa. Arch Virol 143: $1145-1153$

Harmon P (2014) Mosaic disease of St. Augustinegrass caused by sugarcane mosaic virus. University of Florida. http://edis.ifas.ufl.edu/ pdffiles/pp/pp31300.pdf

Harmon P, Alcalá-Briseño R, Polston J (2015) Severe symptoms of mosaic and necrosis in cv. Floratam St. Augustinegrass associated with sugarcane mosaic virus in neighborhoods of St. Petersburg, FL. Plant Dis 99:557

Hort Innovation (2019) Project report TU17005: Australian Turf Industry 2017/18 snapshot report. https://www.horticulture.com.au/growers/ help-your-business-grow/research-reports-publications-fact-sheetsand-more/australian-turf-industry-201718-snapshot-report/

Langeveld SA, Dore J-M, Memelink J et al (1991) Identification of potyviruses using the polymerase chain reaction with degenerate primers. J Gen Virol 72:1531-1541

Nigam D, LaTourrette K, Souza PFN, Garcia-Ruiz H (2019) Genomewide variation in potyviruses. Front Plant Sci 10:1439 
Pares R, Gillings M (1990) Two new records of diseases caused by potyviruses in Australia. Australas Plant Pathol 19:36-37

Sauer JD (1972) Revision of Stenotaphrum (Gramineae: Paniceae) with attention to its historical geography. Brittonia 24:202222

Shukla DD, Tosic M, Jilka J, Ford R, Toler R, Langham M (1989) Taxonomy of potyviruses infecting maize, sorghum and sugarcane in Australia and the United States as determined by reactivities of polyclonal antibodies directed towards virus-specific N-termini of coat proteins. Phytopathology 79:223-229

Teakle D, Grylls N (1973) Four strains of sugarcane mosaic virus infecting cereals and other grasses in Australia. Aust J Agric Res 24:465477
Thomas JE, Steele V (2011) First report of Panicum mosaic virus in buffalo grass (Stenotaphrum secundatum) from Australia. Australas Plant Dis Notes 6:16-17

Todd EH, Abbott E, Tippett R (1964) Sugarcane mosaic on St. Augustine grass in Florida. Plant Disease Reporter 48:442-445

Wu L, Zu X, Wang S, Chen Y (2012) Sugarcane mosaic virus-long history but still a threat to industry. Crop Prot 42:74-78

Xiao XW, Frenkel MJ, Teakle D, Ward CW, Shukla DD (1993) Sequence diversity in the surface-exposed amino-terminal region of the coat proteins of seven strains of sugarcane mosaic virus correlates with their host range. Arch Virol 132:399-408

Yang Z, Mirkov T (1997) Sequence and relationships of sugarcane mosaic and sorghum mosaic virus strains and development of RT-PCRbased RFLPs for strain discrimination. Phytopathology 87:932-939 